\title{
THE INFLUENCE OF HEALTH EDUCATION TOWARD THE LEVEL OF KNOWLEDGE AND MOTIVATION IN THE USE OF FAMILY PLANNING PROGRAMS WITH THE LONG-TERM METHOD OF CONTRACEPTION
}

\author{
Pradista Harini ${ }^{1)}$, Arum Lusiana ${ }^{2)}$, Sri Widatiningsih ${ }^{3)}$ \\ pradista.harini@gmail.com \\ Health Polytechnic of Semarang \\ Midwifery Bachelor Study Program of Magelang
}

\begin{abstract}
Background: Family planning is an effort to regulate the birth of children, distance, and the ideal age for giving birth, regulating pregnancy, through promotion, protection, and assistance by reproductive rights to create a quality family. Efforts to health education about contraception can increase knowledge that can influence the attitudes and motivations that exist in someone to take action in choosing a contraceptive method.

Purpose : The purpose of this study was to determine the effect of health education on the level of knowledge and motivation in the use of MKJP in women of childbearing age.

Methods: This research was conducted in Wuwuharjo Village, Kajoran District, Magelang Regency. This study uses One Group Pretest and Postest correlation analysis with a crossectional approach and sampling using the Systematic Random Sampling method. The respondents used were 80 people. Data collection was done by questionnaire instruments and data were analyzed bivariate by testing Marginal Homogeneity and McNemar.

Result: The results of the study show that there is an influence between health education on the level of knowledge and motivation in using MKJP in women of childbearing age. This can be seen from the significance value produced $<0.1$.

Conclusion: The recommendation for further research is about the routine of health education by using media that are appropriate to the needs of educational routines that increase the knowledge and motivation of women of reproductive age couples in contraceptive use.
\end{abstract}

Keywords: health education; knowledge; motivation; use long-term; contraception

1) Student at the Midwifery Bachelor Study Program Magelang of Health Polytechnic Of Semarang

2,3) Lecturer at the Midwifery Bachelor Study Program Of Magelang of Health Polytechnic Of Semarang

Background. The National family planning program movement has been successfully encouraged by the increasing participation of the community in building small families that are increasing independent. This Success is absolutely to be observed even continuously improved because the achievement is not evenly distributed. The success of Program
Family Planning called KB (keluarga berencana), Quantitatively seen in the prevalence of use of contraception by a fertile age couple called PUS (women of childbearing age), while this family planning activity is still lacking in the use of long-term contraceptive methods called MKJP ((long term contraceptive method) (Manurung, PM, 2012). 
The use of MKJP (long term contraceptive method) is still very low due to the lack of the role of health workers provide information about excess MKJP methods so that the knowledge of society is still lacking. Total number of active KB participants, only $17.45 \%$ of them are using KB MKJP. While $81.23 \%$ of the other users $\mathrm{KB}$ non MKJP and $1.32 \%$ use traditional method of $\mathrm{KB}$ (Kemenkes RI, 2017).

MKJP is more efficient than non MKJP in the availability of budgets and the provision of contraception as well as more effective due to the level of adverse effects, complications and lower failure rates by using MKJP In addition will save expense expenses One does not need to visit often to get a re-contraceptive device and quickly restore fertility. MKJP has a higher level of effectiveness, but every year the number of non cash MKJP in Indonesia has always experienced an increase compared to MKJP (IUD, Implant, MOW and MOP) that tends to decline (Septalia and Puspitasari, 2016). The results of the survey at Puskesmas Kajoran II in July 2018, known as number of PUS 4,701 and became active $\mathrm{KB}$ acceptor as many as $3,777 \quad(80.28 \%)$ Where the percentage of nonMKJP contraceptive users at the health canter in Kajoran II about 53, 92\% and MKJP is only $26.36 \%$ of which of the 14 villages in the working area of Kajoran II, Wuwuharjo Village is a village that has the most number of PUS, which uses KB NonMKJP as much as 466 people while using $\mathrm{KB}$ MKJP only 175 people.

The health education efforts of contraception can increase the knowledge that is able to influence the attitude and motivation that exists in the person to perform an action in choosing a method of contraception. Health education about contraception includes information about the meaning of contraception, contraceptive benefits, contraceptives, benefits, number of failures, side effects, and the cost of each type of contraception (Mayasari, Ayu Citra., Budiarti, Astrida., Enggar, 2017). Low female motivation to use contraceptives will have an impact on the complications of illness during pregnancy, childbirth, complications of nifas time and the high mortality rate of mothers (Rismawati, 2012).

Preliminary study results that researchers have done on October 6, 2018 against 10 respondents in the village of Kajoran District, Magelang District, interviewed when preliminary data retrieval indicates that they do not use the KB method Long term and obtained 2 people know about the understanding of implants without knowing other longterm $\mathrm{KB}$ methods and only 1 person who knows about the KB IUD while 7 others only know the KB pills and injections alone because on Generally PUS in Wuwuharjo village is an acceptor of $\mathrm{KB}$ pills and syringes, from the ignorance of the women of the fertile age about the complete information method of the motive MKJP motivation to use it will also get lower. The health education efforts of contraception can increase the knowledge that is able to influence the attitude and motivation that exists in the person to perform an action in choosing a method of contraception. Health education about contraception includes information 
about the meaning of contraception, contraceptives, benefits, number of failures, side effects, and the cost of each type of contraception (Mayasari, Ayu Citra, Budiarti, Astrida., Enggar, 2017).

Low female motivation to use contraceptives will have an impact on the complications of illness during pregnancy, childbirth, complications of nifas time and the high mortality rate of mothers (Rismawati, 2012).

Results of interviews with midwives coordinator and village midwives in the Wuwuharjo village efforts that have been carried out healthcare personnel to increase the acceptor KB MKJP, especially efforts to deliver pregnancy is by providing education or health education to Community in every meeting Posyandu, but until now users KB MKJP still classified as low because of information or material about the KB MKJP given less complete like anyone who can and who should not use KB MKJP and the process For installation so there are some mothers who claimed to be still afraid to use the KB MKJP.

Purpose. This study will explain about the effect of health education on knowledge levels and motivation in the use of KB MKJP on women of childbearing age.

Methods. This study is Preexperiment One Group Pretest Postest Design with a Cross Sectional approach. Hypothesis in this study is "there is an influence of health education on the level of knowledge and motivation in the use of $\mathrm{KB}$ MKJP in women of childbearing age". The free variables in this study are health education and variables tied are the knowledge and motivation of the women of childbearing age about the use of KB MKJP.

The population in this study is that all mothers who use the method of KB Non MKJP in Wuwuharjo Village amounted to 466 people. The sampling technique used in this study was Systematic Random Sampling (a randomly-systematic sampling). Univariate analysis on this research will be conducted normality test to find mean as well as median in motivation variable before and after intervention, while in bivariate analysis using Mc Nemar test to evaluate design Pretests and Postest Research Group on motivational variables, while hypothesis test to evaluate the design of pretests and Postest research group on knowledge variables using the Homogeneity Marginal test due to data categories including data Category multinominal more than $2 \times 2$.

Results And Discussion. This study was held in March-April 2019 in Wuwuharjo village, Kajoran District, Magelang Regency. The research aims to determine the influence of health education and the Level of knowledge and motivation in the use of KB MKJP in women of childbearing age. Data collection in this study uses primary data that researchers directly took in the field by distributing questionnaires. The study was conducted on 80 respondents. Based on the data obtained in the study will be presented in tabular and narrative form.

The results of this study consist of two types of analysis: univariate analysis and bivariate analysis. Univariate analysis is used to determine the level of knowledge and 
motivation before and after the health education is given, while the bivariate analysis is used to determine the effect of health education on the level of knowledge and Motivation in the use of KB MKJP in women of childbearing age.

\section{Univariate Analysis}

a. Level of knowledge and motivation before the provision of health education in respondents. It can be noted that the proportion of respondents ' knowledge of the use of longterm contraceptives occupies the categories. From the data above, most of the respondents had enough knowledge of 46 people $(57.5 \%)$, respondents who had a good knowledge of 26 people $(32.5 \%)$, and only 8 people $(10.0 \%)$ who have less knowledge. While the proportion of the respondents motivation divided into strong and weak categories. Based on the data, most of the respondents have a strong motivation to use long term contraceptives that are as much as 4 people $(5 \%)$ And the remainder had a weak motivation of 76 people ( $95 \%$ ).

b. Level of knowledge and motivation after provision of health education in respondents. The level of knowledge of respondents after being given health education does not occupy each category. From the above data, it can be known that most have a good level of knowledge of 60 people (75\%), 20 people $(25 \%)$ Who have sufficient knowledge, and less unearned levels of knowledge in respondents. While the motivation rate of respondents occupying a strong category increased to 60 people (75\%) And who have weak motivation decreased to 20 (25\%).

\section{Bivariate Analysis}

a. Analysis of the influence of health education on the level of knowledge in the use of longterm contraceptives in the female PUS where the coefficcent correlates to Marginal Homogenity with MH statistic of-6.332.H statistic

b. Analysis of the influence of health education on motivation level. It can be known to know the analysis of the influence of health education about KB MKJP against the level of motivation in women of PUS acquired coeffictions of correlation $\mathrm{p}=0,008$, the result shows there is a difference in motivation level before and after administration Health education because the result $p=$ 0,008 and $\mathrm{P}<0.1$ then Ho rejected and $\mathrm{Ha}$ accepted meaning there is an influence of health education about KB MKJP against the level of motivation in the women of PUS Wuwuharjo village, Kajoran District, Magelang Regency.

One way of improving the knowledge of long term contraceptive methods is to provide health education. A Joint Committee on terminology in Health Education of United States, 1951 in (Machfoedz et al., 2009) Defines health education is a process that encompasses the 
dimensions and activities of intellectual, psychologically, and socially needed to improve human capacity in conscious decisionmaking and influencing self-welfare, family, and society.

Knowledge level and motivation before the provision of health education. In the study found before given health education about KB MKJP There were 26 respondents (32.5\%) Who have good knowledge, $46(57.5 \%)$ People with sufficient knowledge, and 8 respondents (10\%) who have less knowledge. The most widely answered problem when pretests is question number 12 is about the side effects of long-term contraceptives, especially steady contraceptives. While respondents who have a weak motivation level before being given a health education as much as 76 respondents (95\%) There are as many as 4 respondents (5\%) Who have strong motivation before being given a health education.

\section{Knowledge level and} motivation after providing health education. After the health education was given 60 respondents (75\%) With good knowledge, 20 respondents (25\%) Who have sufficient knowledge, and that no respondent has less knowledge. The most widely answered problem at the time of Posttest is number 13 about the effectiveness of long-term contraceptives. Health education also affects the level of motivation for female PUS that can be seen from respondents who have a weak motivation before being given a health education of 36 respondents (45\%) to 20 people (25\%) After being given a health education, while as many as 44 respondents (55\%) Strong motivation before being given a health education increased to 60 respondents (75\%) After being given health education on long-term contraceptives.

Analysis of health education influence on knowledge level and motivation. Based on the bivariate test results using the Marginal Homogenity, the coefficence gained the correlation of Marginal Homogenity with MH statistic of6.332 indicating that an influential health education $6 x$ folding to the prior and after knowledge Provision of health education and results $\mathrm{P}=$ 0,000 because $\mathrm{P}<0.1$ then $\mathrm{Ho}$ rejected and $\mathrm{Ha}$ accepted meaning there is an influence of health education in the use of KB MKJP against the level of knowledge in the female PUS and test results Mc Nemar obtained coefficseness correlation $\mathrm{p}=0.008$, the results showed there was a difference in motivation level before and after the provision of health education because based on bivariate test results using Marginal Homogenity, acquired coeffictions of Marginal Homogenity with MH Statistic of-6.332 indicating that the health education of $6 \mathrm{x}$ affects the knowledge before and after the provision of health education and the result $\mathrm{P}=0,000$ because $\mathrm{P}$ is $<0.1$ then Ho is rejected and $\mathrm{Ha}$ accepted meaning there is an educational influence Health in the use of $\mathrm{KB}$ MKJP against the level of knowledge in the female PUS and test results Mc Nemar obtained coefficcent correlation $\mathrm{p}=0,008$, the results indicate there is a difference in motivation level before and after the provision of health education because Result $\mathrm{p}=0,008$ and $\mathrm{P}<0.1$ then Ho 
rejected and $\mathrm{Ha}$ accepted meaning there is an influence of health education in the use of KB MKJP against the level of motivation in women Pusresult $\mathrm{p}=0,008$ and $\mathrm{p}<0$, then $\mathrm{Ho}$ rejected and $\mathrm{Ha}$ accepted meaning there is an influence of health education In the use of KB MKJP against the level of motivation in women PUS.

So, it can be concluded that the results of the hypothesis testing in this study showed the influence of health education on the level of knowledge and motivation in the use of $\mathrm{KB}$ MKJP in women of childbearing age in Wuwuharjo village, Kecamatan Kajoran, Magelang regency.

Knowledge is the result of the know and it happens after people do the sensing of a particular object. Tofu is interpreted as a verb for measuring what is included in remembering the recall of something previously learned. Most of human knowledge is gained through the eyes and ears. The more senses used to receive something the more and more and more knowledge and understanding obtained from information (Notoatmodjo, 2014).

Improved knowledge can be seen from the respondents ability to answer pretests and postest problems. Before the pretests of the answered right most of the increase was improved while the problem that was answered wrong mostly decreased during posttest. But there is a question that when Pretests gets a good score becomes less when the Postest is located on the number of questions 7 and 13 that contain material about the side effects and effectiveness of IUD. Based on the data obtained can be concluded that after obtaining the health education respondents have improved knowledge because they have been informed clearly.

It is strengthened by the results of the research conducted by Susilawati, the higher the level of knowledge of one then the easier to digest all the information obtained, so that the decision is based on rational thinking ( Susilawati, 2013).

The results of the research of Ridho Hidayatulloh (2017) also proved that the results of one $\mathrm{T}$ test test showed an average difference of 3.85. $\mathrm{T}$ Test value $=11,117, \mathrm{p}$-value $=0.001$ value. $\mathrm{P}$-value of 0.001 , and increasing the knowledge of respondents about the KB IUD after obtaining a health education of $38.21 \%$ and the decision taken is Ho rejected, meaning that health education affects mothers ' knowledge About KB IUD in research in Plosorejo Hamlet Jagir Village District Sine Ngawi District in April 2017 (Hidayatulloh, 2017).

Based on research conducted by (Hardiningsih, Yuneta and Yunita, 2017) obtained from analysis using Wilcoxon signed test Ranks can be known influence of health education on the knowledge of the fertile age mates Respondents amounting to 76 people. The average value obtained by the respondent about the knowledge before the health education was 13.43 showed that the knowledge of the fertile age pair about implant contraceptives is still lacking, and after health education is given The average rate of respondents on the knowledge of implant contraceptives increased to 21.04 indicating that the knowledge of the fertile age pair of implant 
contraceptives is better than before being given an education Health.

Motivation can be said a series of attempts to provide certain conditions, so that someone wants and wants to do something, and if it does not like it will try to negate or eliminate the feeling of dislikes. So, that motivation grows from within a person but motivation can also be stimulated by outside factors (Sardiman, 2016).

In this study most of the respondents had a strong motivation before being given health education but after being given health education, the number of respondents who had strong motivation increased from 44 to 60 respondents and 36 Respondents with weak motivation decreased to 20 respondents after being given a study. This is in accordance with the theory that there are 2 kinds of motivation: intrinsic and extrinsic motivation. Intrinsic motivation is a motivation that does not need to be stimulus from the outside because from within each individual there is already an encouragement to do something and absolutely really want to know everything not because it wants to be given a compliment. While extrinsic motivation is a motivation arising from outside stimulation that is not absolutely related to learning activities (Sardiman, 2016; H. 86-91).

The theory is reinforced by the results that obtained a significant value $=0.001<\alpha(0.05)$ which means that the data is significant and accepts Ha meaning "there is a health effect on the $\mathrm{KB}$ on motivation to choose contraceptives in Bera Village of West Sumba NTT ". A person who has motivation or encouragement born from within himself will be easier to achieve success compared to those who need motivation or a driving factor that comes from outside of him. This is because of the initiative or willingness and desire to be expected by someone motivated by the intristic. Usually such a person who has the other active nature with the person who has passive nature should always be moved by the other so that the willingness to reach the goals is a little sluggish. Therefore, it is necessary to increase the frequency of administration of women who are married (PUS) and have children so that it can have an understanding and insight in the use of contraceptives (Ulle, Utami and Susmini, 2017).

A study in journalism also showed that the Wilcoxon match pairs testtest results with a significant level of 0.05 were found to count < significant levels with a result of 0.001 . The result can be interpreted that $\mathrm{Ha}$ is acceptable, so it can be concluded that there is a health education influence peer group about IUD contraceptives to the level of motivation of mothers using IUD contraceptives in the district of Caring, Samigaluh, Kulon Progo (Baihaqi, 2016).

In this research researchers cooperate with cadres and village midwives in providing health education. Researchers provide a long-term understanding of contraceptive media using a counterfacet and a direct question to the respondent with the expectation after the woman's health education of a fertile age couple can increase her knowledge and Motivated to berKB primarily using long-term contraceptives. The most widely used 
type of contraceptives in the region are pills and injections, this is because the understanding of the long term contraceptive equipment is still low and the motivation given by midwives is only given when After childbirth and the sound of discordant from its terrible environment, for example, pain arises during installation, pain when connecting, and the most is due to embarrassment during the installation process.

According to Lasut et al. (Nursalam, 2009), health education has a specific purpose namely change of knowledge (cognitive), attitude (understanding and motivation), or practical (access information and use information) to maintain its health (LASUT, Palandeng and Bidjun, 2013).

\section{Conclusion and Suggestions.}

1. Before the health education was given most of the respondents had enough knowledge are 46 people (57.5\%). Most of the respondents have had a strong motivation for long term contraceptive use are 46 people $(55 \%)$.

2. The rate of knowledge of respondents has increased after being given health education from $32.5 \%$ to $75 \%$ of wellknowledgeable respondents. While the motivation level of respondents in the use of long-term contraceptives also increased after being given a health education that is as much as $95 \%$ of respondents with weak motivation to $25 \%$ of respondents.

3. There is the influence of health education to the level of knowledge and motivation in the women of PUS in the use of KB MKJP in Wuwuharjo village,
Kajoran District, Magelang Regency.

Recommendation for health service provider is providing education and motivation not only in NIFAS patients or only in people who come to use planing family program, but further increase the frequency of providing health education at regular events or meetings that target women in childbearing age.

The education is especially giving explanation about the effectiveness and side effects of longterm contraceptives methode by following the training related to the $\mathrm{KB}$ in order to be Increase the knowledge and motivation about MKJP for the women in childbearing age.

\section{References}

Affandi, B. (2014) Buku Panduan Praktis Pelayanan Kontrasepsi. 3rd edn. Jakarta: PT Bina Pustaka Sarwono Prawirodiharjo.

Badan Pusat Statistik et al. (2015) 'Situasi Keluarga Berencana di Indonesia', Jurnal Populasi, pp. 102-114. doi: 2101018.

Baihaqi, A. H. B. (2016) 'Pengaruh Pendidikan Kesehatan Peer Group Terhadap Motivasi ibu Menggunakan Kontrasepsi IUD di Dusun Tukharjo Purwoharjo Samigaluh Kulon Progo Yogyakarta'.

Dinas Kesehatan Jateng (2016)Profil Kesehatan Provinsi Jawa Tengah. Semarang: Dinas Kesehatan Provinsi Jawa Tengah.

Dinas Kesehatan Kabupaten Magelang (2017)Profil Kesehatan Kabupaten Magelang 
Tahun 2016.

Darmadi (2018)Manajemen Sumber Daya Manusia

Kekepalasekolahan. Yogyakarta: Deepublish.

Gaol, E. L. (2017) 'Pengaruh Faktor Predisposisi, Pendukung dan Pendorong Terhadap Pemanfaatan KB MKJP pada Wanita Pasangan Usia Subur di Wilayah Kerja Puskesmas Hutapaung Kecamatan Pollung Kabupaten Humbang Hasundutan Tahun 2017'.

Hartanto, H. (2013) Keluarga Berencana dan Kontrasepsi. Jakarta: Pustaka Sinar Harapan.

Hardiningsih, Yuneta, A. E. N. and Yunita, F. A. (2017) 'Pengaruh Penyuluhan Terhadap Tingkat Pengetahuan Wanita Usia Subur Tentang Alat Kontrasepsidi Wilayah Kerja Puskesmas Sangkrah Kota Surakarta', Jurnal Kesehatan Kusuma Husada, pp. 11-15.

Hasmiatin (2016) 'Hubungan Dukungan Suami dan Budaya dengan Penggunaan Kontrasepsi Implant pada Pasangan Usia Subur'. Available at: http://fid311072-sitedi-skripsipdf.

Hidayat, A. A. (2012)Riset Keperawatan dan Penelitian Ilmiah Edisi 2. Jakarta: Salemba Medika.Irwanto (2008) Motivasi dan Pengukuran Perilaku. Jakarta: PT Rineka Cipta.

Hidayatulloh, R. (2017) 'Pengaruh Pendidikan Kesehatan Terhadap Pengetahuan Ibu-Ibu tentang KB IUD di Dusun Plosorejo Desa Jagir Kecamatan Sine Kabupaten Ngawi'.

Kaseuntung, C., Kundre, R. and
Bataha, Y. (2015) 'Pengaruh Penyuluhan Kesehatan Terhadap Pengetahuan Wanita Usia Subur (WUS) dalam Pemilihan Kontrasepsi di Desa Kalama Darat Kecamatan Tamako Kepulauan Sangihe', 3.

Kemennkes RI (2017)Profil Kesehatan Indonesia Tahun 2017. Jakarta.

Khairunnisa, I. (2018) 'FaktorFaktor yang Berhubungan dengan Minat Pasangan Usia Subur dalam Mengikuti Program KB di Desa Jaraksari Kabupaten Wonosobo'.

Lasut, V. M., Palandeng, H. and Bidjuni, H. (2013) 'Pengaruh Pendidikan Kesehatan Terhadap Pengetahuan PUS Tentang Alat Kontrasepsi Implan di Wilayah Kerja Puskesmas Nuangan Bolaang Mongondow Timur'.

Machfoedz, I. et al. (2009)Pendidikan Kesehatan Bagian dari Promosi Kesehatan. Yogyakarta: Fitramaya.

Manuaba, I. A. C., Manuaba, I. B. G. F. and Manuaba, I. B. G. (2010)Ilmu Kebidanan, Penyakit Kandungan, dan KB. 2nd edn. Jakarta: EGC.

Manurung, PM, D. (2012) 'Analisis Faktor Yang Memengaruhi Akseptor Kb Dalam Memilih Alat Kontrasepsi Iud Di Desa Wonosari Kecamatan Tanjung Morawa Kabupaten Deli Serdang Tahun 2012', 3, pp. 1-9. Marmi (2016) Buku Ajar Pelayanan $K B$. Yogyakarta: Pustaka Pelajar. Mayasari, Ayu citra., Budiarti, Astrida., Enggar, A. (2017) 'Pemilihan Penggunaan Alat Kontrasepsi Pada Akseptor KB ( di Rw 03 Kelurahan Kedung 
Cowek Surabaya )', pp. 20132018.

Mubbarak, W. I. and Cahyatin, N. (2009)Ilmu Keperawatan

Komunitas. Jakarta: Salemba Medika.

Notoatmodjo, S. (2010)Ilmu Perilaku Kesehatan. Jakarta: Rineka Cipta.

Notoatmodjo, S. (2012)Metodologi Penelitian Kesehatan. Jakarta: Rineka Cipta.

Notoatmodjo, S. (2014)Promosi Kesehatan dan Perilaku Kesehatan. Jakarta: Rineka Cipta.

Nurul Farahan M.S (2016) 'Gambaran Tingkat Pengetahuan Penggunaan Alat Pontrasepsi pada Wanita Usia Subur dan Dukungan Petugas di Desa Bebandem Kabupaten Karangasem Bali', E-Jurnal Medika, 5(4), pp. 1-12. doi: 10.1257/jep.5.2.25.

Rismawati, S. (2012) 'Unmet Need: Tantangan Program Keluarga Berencana dalam Menghadapi Ledakan Penduduk Tahun 2030'. Sardiman (2016) Interaksi dan Motivasi Belajar Mengajar. Jakarta: Rajawali Pers.

Septalia, $R$. and Puspitasari, $N$. (2016) 'Faktor yang Mempengaruhi Pemilihan Metode Kontrasepsi', Jurnal Biometrika dan Kependudukan, 5(2011), pp. 91-98.

Setiyaningrum, E. (2015) Pelayanan Keluarga Berencana dan
Kesehatan Reproduksi. Revisi. Jakarta: CV. Trans Info Media.

Survei Demografi dan Kesehatan Indonesia 2012 (2013). doi: $10.1111 / \mathrm{j} .1471-$ 0528.2007.01580.x.

Susilawati, F. (2013) 'Gambaran Minat Wanita Usia Subur dengan Pemilihan Alat Kontrasepsi Implant di Wilayah Kerja Puskesmas Meureudu Kecamatan Meureudu Kabupaten Pidie Jaya'.

Sugiyono (2015) Statistika untuk Penelitian. Bandung: Alfabeta.

Trisnawati, L. et al. (2011) 'Hubungan Antara Pengetahuan Tentang $K B$

MKJP dan Sikap Ibu Peserta Jampersal Pasca Persalinan dengan Penggunaan KB MKJP di Puskesmas Kartasura', (3), pp. $1-15$.

Ulle, A. J., Utami, N. W. and Susmini (2017) 'Pengaruh Penyuluhan Kesehatan Tentang KB Terhadap Motivasi dalam Memilih Alat Kontrasepsi di Desa Bera Dolu Sumba Barat Nusa Tenggara Timur (NTT)', 2 , pp. 1-9.

Varney, H., Kriebs, J. M. and Gegor, C. L. (2009) Buku-Ajar Asuhan Kebidanan. 4th edn. Jakarta: EGC.

Wawan and Dewi (2010) Teori dan Pengukuran Penngetahuan, Sikap, dan Perilaku Manusia. Yogyakarta: Nuha Medika. 